\title{
Penerapan Kaizen Untuk Mengurangi Loss Time Dalam Peningkatan Produktivitas Mesin Infrared Welding (Studi Kasus PT. Mitsuba Indonesia)
}

\section{Implementation of Kaizen To Reduce Loss Time In Improving Productivity Of Infrared Welding Machine (Case Study of PT. Mitsuba Indonesia)}

\author{
Hartono $^{1}$, Fatkhurozi $^{2}$ \\ 1,2. Program Studi Teknik Industri, Fakultas Teknik, Universitas Muhammadiyah Tangerang \\ hartono@umt.ac.id, 2rozie0804@gmail.com
}

\begin{abstract}
PT Mitsuba Indonesia is a factory engaged in the manufacture of electrical automotive spare parts. The LED winker lamp is the newest product whose production demand is always increasing. The large demand for LED winker lamp products must of course be balanced with the readiness of production machines which are always in good condition. But in practice, the results of the production achievement are still low, this is due to the high machine loss time, especially in infrared welding machines. This study discusses the application of kaizen which aims to find the causes of loss time, make improvements in order to reduce loss time and determine loss time and productivity after repairs are made. The method used to analyze the causes of loss time is to calculate the value of six big losses and analysis of the cause and effect diagram. The analysis results showed that the idling minor factor and stoppages losses caused by part drop error and the set up and adjustment losses factor caused by a change in the type of production jig. Improvements made to the part drop error were adding 1 set of regulators. Meanwhile, the change in the production jig type is to modify the locking system on the lower and upper heater jig. Based on these improvements, it was able to reduce the loss time to $4.86 \%$ and productivity to increase $7.50 \%$ in July. Loss time fell $4.70 \%$ and productivity increased $7.90 \%$ in August.
\end{abstract}

Keywords: LED winker lamp, infrared welding machine, loss time, six big losses, productivity.

\begin{abstract}
ABSTRAK
PT Mitsuba Indonesia merupakan pabrik yang bergerak dibidang pembuatan electrical automotive spareparts. LED winker lamp merupakan produk terbaru yang permintaan produksinya selalu meningkat. Besarnya permintaan produk LED winker lamp tentunya harus diimbangi dengan kesiapan mesin produksi yang selalu dalam kondisi baik. Tetapi dalam pelaksanaannya hasil pencapaian produksi masih rendah, hal ini disebabkan oleh tingginya loss time mesin, terutama pada mesin infrared welding. Penelitian ini membahas penerapan kaizen yang bertujuan untuk mencari penyebab - penyebab loss time, melakukan perbaikan guna menurunkan loss time dan mengetahui loss time dan produktivitas setelah dilakukan perbaikan. Metode yang digunakan untuk analisis penyebab loss time adalah dengan menghitung nilai six big losses dan analisis diagram sebab akibat. Hasil analisis didapatkan faktor idling minor and stoppages losses yang disebabkan oleh part drop error dan faktor set up and adjustment losses yang disebabkan oleh pergantian tipe jig produksi. Perbaikan yang dilakukan pada part drop error yaitu dengan menambah 1 set regulator. Sedangkan pada pergantian tipe jig produksi yaitu memodifikasi sistem penguncian pada lower and upper heater jig. Berdasarkan perbaikan tersebut mampu menurunkan loss time menjadi 4,86\% dan produktivitas naik 7,50\% pada bulan Juli. Loss time turun 4,70\% dan produktivitas naik 7,90\% pada bulan Agustus.
\end{abstract}

Kata kunci: LED winker lamp, Mesin infrared welding, Loss time, Six big losses, Produktivitas. 


\section{PENDAHULUAN}

\subsection{Latar Belakang}

Setiap perusahaan baik perusahaan manufaktur maupun jasa akan terus meningkatkan produktivitas perusahaannya dalam segala aspek. Dalam perusahaan manufaktur, produktivitas suatu perusahaan dapat dilihat dari kemampuan perusahaan dalam menjalankan proses produksi secara efektif dan efisien. Semakin efisien sistem produksi dalam suatu perusahaan, maka semakin sedikit timbulnya waste dalam proses produksi. Hal tersebut dapat dilihat dari hasil capaian target produksi mereka.

PT. Mitsuba Indonesia merupakan perusahaan yang bergerak di bidang pembuatan electrical automotive spareparts. Produk yang di produksi oleh PT. Mitsuba Indonesia diantaranya LED winker lamp, Horn, Relay, Starter motor, Fuel pump, ACG, Fly wheel dan Wiper. LED winker lamp merupakan produk terbaru PT. Mitsuba Indonesia yang permintaan produksinya selalu meningkat dan merupakan produk dengan teknologi baru yang tergolong sukses di pasar. Saat ini teknologi lampu yang digunakan untuk produk otomotif mulai beralih menggunakan teknologi lampu LED (Light Emitting Diode) dari yang semula menggunakan lampu halogen, hal ini disebabkan lampu LED lebih tahan lama, hemat energi dan menghasilkan pencahayaan dan warna sinar yang lebih baik jika dibandingkan dengan lampu halogen. Besarnya permintaan produksi LED winker lamp tentunya harus diimbangi dengan kesiapan mesin / peralatan produksi yang selalu dalam kondisi baik.

Berdasarkan data perusahaan selama tahun 2019 loss time mesin rata - rata yaitu 7,09\%. Sedangkan target atau standar perusahaan loss time yang diperbolehkan yaitu 5\%. Dengan adanya loss time diatas target yang ditetapkan menjadi masalah yang cukup besar karena menyebabkan hasil pencapaian produksi rendah.

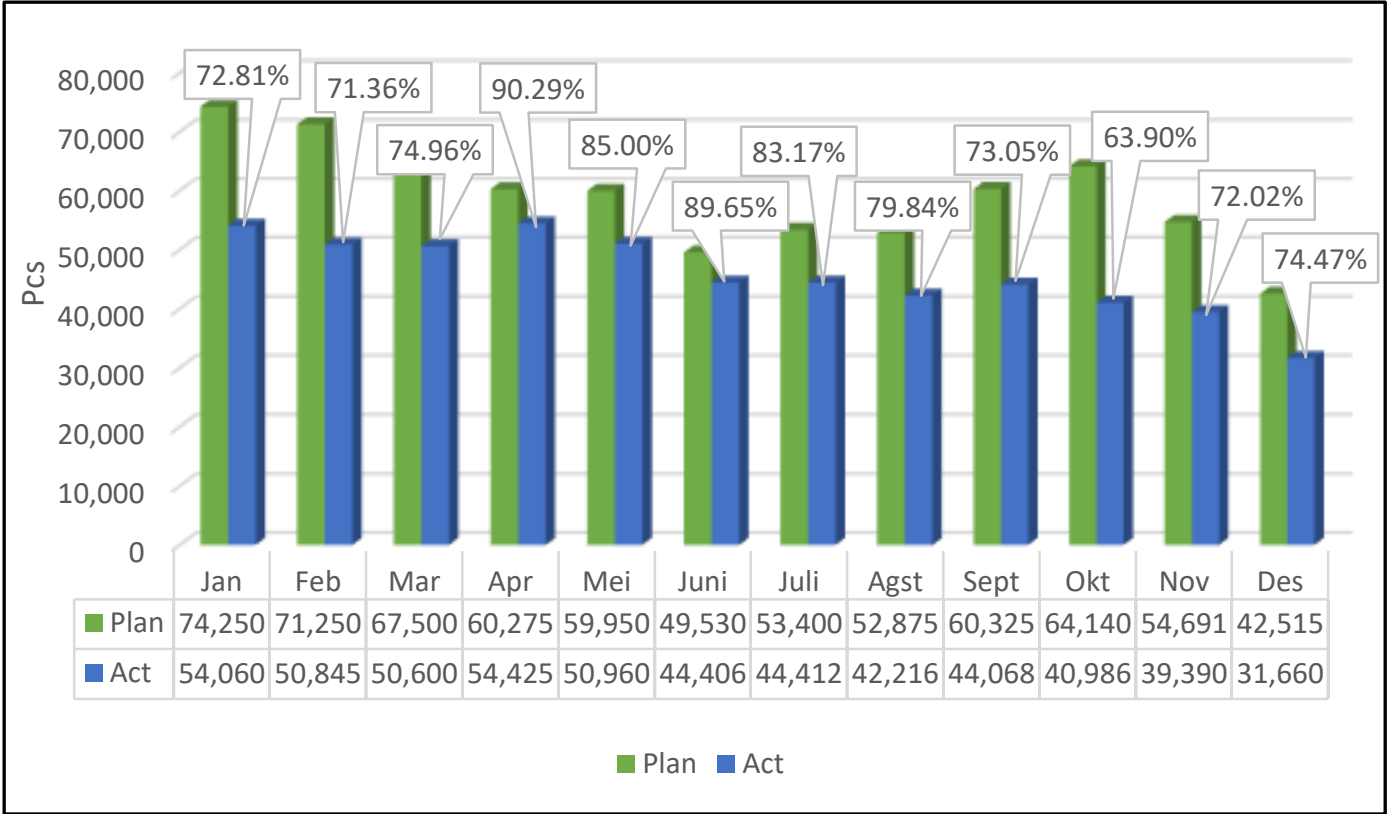

Gambar 1.1 Hasil Pencapaian Produksi LED Winker Lamp Tahun 2019 Sumber : PT. Mitsuba Indonesia

Berdasarkan gambar diatas, hasil pencapaian produksi LED winker lamp pada tahun 2019 masih dibawah standar perusahaan yaitu sebesar 77\%, sedangkan target atau standar perusahaan yaitu sebesar $80 \%$. 


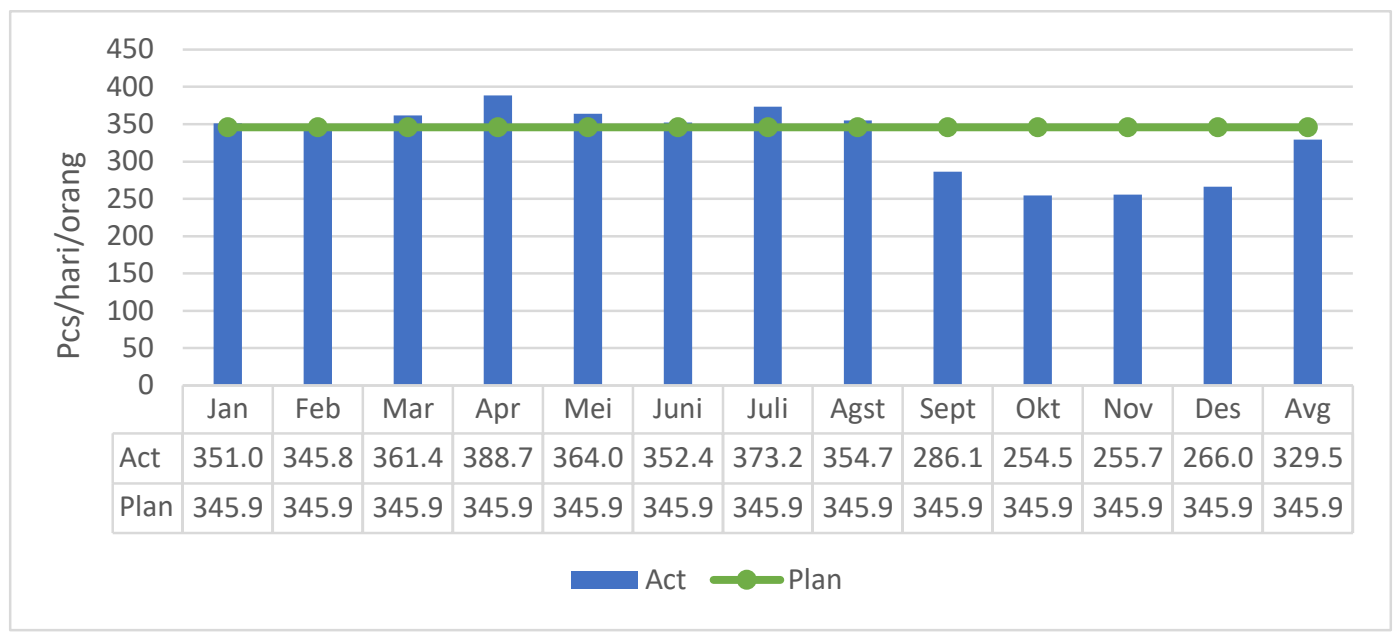

Gambar 1.2 Produktivitas lini LED Winker Lamp Tahun 2019

Sumber : PT. Mitsuba Indonesia (telah diolah)

Dan dilihat dari produktivitas pada lini LED Winker Lamp tahun 2019 memiliki rata rata $329 \mathrm{pcs} /$ hari/orang. Sedangkan target pada tahun berikutnya produktivitas diharapkan meningkat 5\% atau sebesar $346 \mathrm{pcs} /$ hari/orang, hal ini merupakan target perusahaan yaitu meningkatkan produktivitas pada setiap tahunnya. Berdasarkan fenomena yang dikemukakan diatas, maka dilakukan penelitian dengan mengambil judul "Penerapan Kaizen Untuk Mengurangi Loss Time Dalam Peningkatan Produktivitas Mesin Infrared Welding di PT. Mitsuba Indonesia".

\subsection{Tinjauan Pustaka}

\section{Loss Time}

Salah satu kerugian yang sering terjadi di perusahaan adalah loss time. Definisi loss time adalah kondisi dimana mesin tidak beroperasi karena kerusakan mesin, gangguan proses, bahan baku habis dan atau sebab lain yang mengakibatkan availability mesin berkurang.

Loss time adalah waktu yang hilang dan yang tidak dapat dipergunakan untuk memberikan nilai tambah pada suatu produk. Adanya loss time dalam suatu proses produksi, akan menyebabkan berbagai kerugian yang harus dihadapi. Terdapat dua jenis kerugian, yaitu kerugian terlihat dan kerugian tidak terlihat. Kerugian terlihat merupakan kerugian yang dapat diketahui secara langsung, contohnya adalah produk reject. Kerugian tidak terlihat merupakan kerugian yang tidak dapat diketahui secara langsung dan biasanya diperlukan penelusuran yang lebih dalam, contohnya adalah loyalitas customer.

\section{Kaizen}

Kaizen merupakan istilah dalam bahasa Jepang terhadap konsep Continous Incremental Improvement. Pendekatan ini hanya berhasil dengan baik apabila disertai dengan usaha sumber daya manusia yang tepat karena manusia merupakan dimensi yang terpenting dalam perbaikan kualitas dan produktivitas. (Singgih, 2008).

\section{Siklus PDCA (Plan, Do, Check, Action)}

Dalam kaizen dikenal dua macam siklus atau aliran yaitu siklus Plan, Do Check, Action (PDCA) dan siklus Standardize, Do, Check, Action, (SDCA). Kedua siklus ini merupakan sarana yang menjamin terlaksanannya kesinambungan dari pelaksanaan kaizen, guna mewujudkan kebijakan memelihara dan memperbaiki atau meningkatkan standar.

\section{Produktivitas}

Menurut Drs. Muchdarsyah Sinungan (2014) konsep produktivitas adalah hubungan antara output dan input. Jadi orientasinya bukan tertuju hanya pada output atau hanya pada 
input melainkan pada keduanya. Oleh karena itu, konsep produktivitas adalah lebih luas dari konsep-konsep yang hanya berorientasi pada satu segi saja(seperti efisiensi, produksi dan efektivitas)

$$
\text { Produktivitas }=\frac{\text { output produksi }}{\text { Waktu Kerja } \times \text { Jumlah Tenaga Kerja }}
$$

Produktivitas yang tinggi berarti hasil produksi yang tinggi dapat dicapai dengan waktu dan jumlah tenaga kerja yang rendah. Hal ini sesuai dengan prinsip ekonomi yang berbunyi "memperoleh hasil yang setinggi tingginya dengan mengorbankan yang sekecil-kecilnya". Bahasa operasionalnya berarti bekerja secara ekonomis sama dengan bekerja secara produktif.

\section{Mesin Infrared Welding}

Infrared welding adalah teknik pengelasan termal non - kontak yang mampu menghasilkan las yang sangat kuat dan kedap udara di bagian termoplastik. Radiasi inframerah paling umum dirasakan dalam bentuk panas yang kita rasakan dari sinar matahari. Seperti halnya segala bentuk cahaya, radiasi inframerah adalah radiasi elektromagnetik yang ditransmisikan pada tingkat daya yang sangat tinggi dengan kecepatan cahaya. Saat menggunakan energi ini dengan cara yang dikontrol ketat, bagian termoplastik dapat dipanaskan dengan suhu yang sangat cepat dan kemudian bergabung bersama dengan cara yang sangat mirip dengan pengelasan hot plate. (forwardtech.com).

Menurut Asseko, dkk (2016) pengelasan inframerah komposit melibatkan dua bagian yang bergabung: satu semi-transparan dengan panjang gelombang IR dan bagian lainnya adalah penyerap dalam panjang gelombang yang sama. Dua bagian diposisikan bersama sebelum pengelasan. Permukaan perawatan tidak diperlukan seperti dalam proses perekatan. Energi sinar inframerah ditransmisikan melalui bahan semi-transparan dan diserap dalam permukaan material kedua. Ikatan antara dua bagian memungkinkan pemanasan bagian semi-transparan dengan konduksi termal.

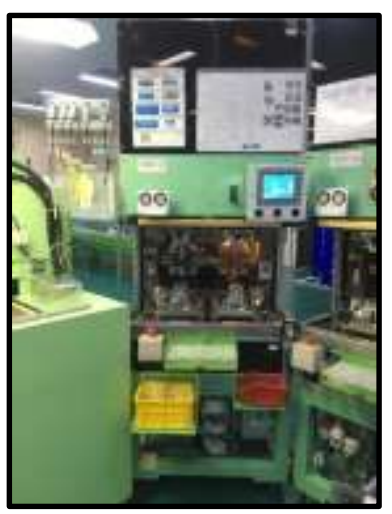

Gambar 2.1 Mesin infrared welding

Sumber : PT Mitsuba Indonesia

\section{METODOLOGI}

\subsection{Teknik Pengumpulan Data}

Penelitian dilakukan di bagian LED Winker Lamp PT Mitsuba Indonesia yang berlokasi di Jalan Siliwangi, Kelurahan Keroncong, Kecamatan Jatiuwung, Kota Tangerang. Pelaksanaan penelitian dilakukan selama 1 tahun. Lingkup penelitian meliputi bagian LED Winker Lamp, kegiatan yang menjadi objek penelitian adalah mesin Infrared Welding. Data yang diperoleh adalah data dari hasil troubleshoot mesin. Dari data yang sudah dikumpulkan kemudian di analisis untuk mendapatkan kesimpulan dan saran.

a) Menemukan masalah loss time 
Pada produksi LED winker lamp assy masalah yang terjadi adalah tingginya loss time. Dengan adanya loss time yang tinggi akan mengurangi produktivitas mesin sehingga hasil pencapaian produksi tidak sesuai target yang ditentukan.

b) Mengambil data loss time pada lini produksi

Pengambilan data berupa loss time mesin dan data hasil pencapaian produksi. Studi lapangan menghasilkan tujuan penelitian untuk menyelesaikan inti masalah tingginya loss time pada lini produksi LED winker lamp assy yang menyebabkan rendahnya hasil ouput produksi.

\subsection{Teknik Pengolahan Data}

Pengolahan dilakukan dari data yang diperoleh pada studi observasi dilapangan yang berupa data loss time dan data produksi. Sedangkan berdasarkan teori pada studi kepustakaan yaitu tentang six big losses maka dilakukan analisis untuk mengetahui penyebab loss time dan diperoleh rekomendasi perbaikannya.

a) Analisis Six Big Losses

Analisis six big losses digunakan untuk mengetahui penyebab loss time untuk selanjutnya dianalisis dengan fishbone diagram untuk mengetahui akar penyebab terjadinya loss time.

b) Analisis Fishbone Diagram

Setelah diketahui permasalahan yang menjadi penyebab tingginya loss time, maka pendefinisian masalah dengan menggunakan fishbone diagram sehingga diperoleh faktor penyebab loss time untuk diberikan rekomendasi perbaikan berdasarkan implementasi kaizen.

\section{HASIL DAN PEMBAHASAN}

\subsection{Pengumpulan Data}

1. Data Produksi Winker Lamp, Loss Time, Loading Time, dan Operation Time

Tabel 3.1 menunjukkan hasil pencapaian produksi pada lini LED winker lamp selama bulan Januari 2019 sampai dengan bulan Desember 2019 yang diperoleh dari arsip dan dokumen hasil catatan harian yang ada pada lini LED winker lamp. Hasil rata - rata pencapaian produksi LED winker lamp pada tahun 2019 mencapai 45.669 pcs, sedangkan rata - rata hasil planning produksi sebanyak 59.225 pcs. Dan apabila dipresentasekan rata - rata hasil pencapaian produksi hanya mencapai $77,54 \%$.

Tabel 3.1 Hasil pencapaian produksi LED winker lamp tahun 2019

\begin{tabular}{|l|c|c|c|}
\hline \multicolumn{1}{|c|}{$\begin{array}{c}\text { Bulan } \\
(2019)\end{array}$} & Plan (Pcs) & $\begin{array}{c}\text { Act } \\
(\mathrm{Pcs})\end{array}$ & $\begin{array}{c}\text { Presentase Act } \\
(\%)\end{array}$ \\
\hline Januari & 74.250 & 54.060 & 72,81 \\
\hline Februari & 71.250 & 50.845 & 71,36 \\
\hline Maret & 67.500 & 50.600 & 74,96 \\
\hline April & 60.275 & 54.425 & 90,29 \\
\hline Mei & 59.950 & 50.960 & 85,00 \\
\hline Juni & 49.530 & 44.406 & 89,65 \\
\hline Juli & 53.400 & 44.412 & 83,17 \\
\hline Agustus & 52.875 & 42.216 & 79,84 \\
\hline September & 60.325 & 44.068 & 73,05 \\
\hline Oktober & 64.140 & 40.986 & 63,90 \\
\hline November & 54.691 & 39.390 & 72,02 \\
\hline
\end{tabular}




\begin{tabular}{|l|l|l|l|} 
Desember & 42.515 & 31.660 & 74,47 \\
\hline Total & 59.225 & 45.669 & 77,54 \\
\hline
\end{tabular}

Sumber : PT Mitsuba Indonesia

Dari hasil pencapaian produksi LED winker lamp diatas dipengaruhi faktor loss time yang diakibatkan dari mesin atau tool yang digunakan dalam proses produksi. Loss time yang timbul akan mengganggu atau menghambat jalannya produksi. Hal inilah yang akan mempengaruhi produktivitas pada lini LED winker lamp. Berikut data untuk loading time dan operation time yang telah dikumpulkan.

Tabel 3.2 Rekapitulasi loading time dan operation time

\begin{tabular}{|l|c|c|c|c|c|c|}
\hline $\begin{array}{c}\text { Bulan } \\
(2019)\end{array}$ & $\begin{array}{c}\text { Waktu } \\
\text { Tersedia } \\
\text { (Jam) }\end{array}$ & $\begin{array}{c}\text { Waktu } \\
\text { Tersedia } \\
\text { (Hari) }\end{array}$ & $\begin{array}{c}\text { Planned } \\
\text { downtime } \\
\text { (Jam/Hari) }\end{array}$ & $\begin{array}{c}\text { Loading } \\
\text { time } \\
\text { (Jam) }\end{array}$ & $\begin{array}{c}\text { Loss } \\
\text { time } \\
\text { (Jam) }\end{array}$ & $\begin{array}{c}\text { Operation } \\
\text { time (Jam) }\end{array}$ \\
\hline Januari & 330 & 22 & 0,5 & 319,00 & 25,30 & 293,70 \\
\hline Februari & 315 & 21 & 0,5 & 304,50 & 16,08 & 288,42 \\
\hline Maret & 300 & 20 & 0,5 & 290,00 & 25,03 & 264,97 \\
\hline April & 300 & 20 & 0,5 & 290,00 & 23,52 & 266,48 \\
\hline Mei & 300 & 20 & 0,5 & 290,00 & 23,08 & 266,92 \\
\hline Juni & 270 & 18 & 0,5 & 261,00 & 15,93 & 245,07 \\
\hline Juli & 255 & 17 & 0,5 & 246,50 & 13,42 & 233,08 \\
\hline Agustus & 255 & 17 & 0,5 & 246,50 & 16,17 & 230,33 \\
\hline September & 330 & 22 & 0,5 & 319,00 & 25,37 & 293,63 \\
\hline Oktober & 345 & 23 & 0,5 & 333,50 & 26,98 & 306,52 \\
\hline November & 330 & 22 & 0,5 & 319,00 & 26,23 & 292,77 \\
\hline Desember & 255 & 17 & 0,5 & 246,50 & 19,00 & 227,50 \\
\hline
\end{tabular}

Sumber : PT Mitsuba Indonesia (telah diolah)

Berdasarkan tabel 4.4 diatas dapat dijabarkan bahwa nilai loading time diperoleh dari waktu yang tersedia diambil total planned downtime, dimana total planned downtime yaitu waktu tersedia dikali planned downtime dalam 1 hari. Sedangkan nilai operation time diperoleh dari hasil pengurangan loading time dan loss time. Berikut ini merupakan total loss time yang ada di lini LED winker lamp.

Tabel 3.3 Data loss time di lini LED winker lamp tahun 2019

\begin{tabular}{|l|c|c|c|}
\hline $\begin{array}{c}\text { Bulan } \\
(2019)\end{array}$ & $\begin{array}{c}\text { Availability } \\
\text { time (Jam) }\end{array}$ & $\begin{array}{c}\text { Loss time } \\
(\mathrm{Jam})\end{array}$ & $\begin{array}{c}\text { Loss time } \\
(\%)\end{array}$ \\
\hline Januari & 330 & 25,30 & 7,67 \\
\hline Februari & 315 & 16,08 & 5,10 \\
\hline Maret & 300 & 25,03 & 8,34 \\
\hline April & 300 & 23,52 & 7,84 \\
\hline Mei & 300 & 23,08 & 7,69 \\
\hline Juni & 270 & 15,93 & 5,90 \\
\hline Juli & 255 & 13,42 & 5,26 \\
\hline Agustus & 255 & 16,17 & 6,34 \\
\hline
\end{tabular}

JIM, Vol. 6, No. 1, Februari 2021, pp.01-18 


\begin{tabular}{|l|c|c|c|} 
September & 330 & 25,37 & 7,69 \\
\hline Oktober & 345 & 26,98 & 7,82 \\
\hline November & 330 & 26,23 & 7,95 \\
\hline Desember & 255 & 19,00 & 7,45 \\
\hline Total & 3.585 & 256,11 & 85,06 \\
\hline \multicolumn{2}{|c|}{ Rata - rata } & 21,34 & 7,09 \\
\hline
\end{tabular}

Sumber : PT Mitsuba Indonesia (telah diolah)

Selanjutnya dari total loss time tersebut dapat di spesifikasikan lagi berdasarkan mesin yang digunakan untuk produksi LED winker lamp.

Tabel 3.4 Loss time mesin di lini LED winker lamp

\begin{tabular}{|l|c|}
\hline \multicolumn{1}{|c|}{ Mesin } & $\begin{array}{c}\text { Loss time } \\
\text { (Jam) }\end{array}$ \\
\hline Screw tightening & 6,75 \\
\hline Screw hight check & 6,19 \\
\hline Infrared welding & 228,32 \\
\hline Air leak inspection & 13,02 \\
\hline Laser marking & 1,83 \\
\hline Total & 256,11 \\
\hline
\end{tabular}

Sumber : PT Mitsuba Indonesia (telah diolah)

Dari tabel 4.5 diatas menunjukkan bahwa jumlah loss time pada lini LED winker lamp tahun 2019 yaitu 256,11 jam, dengan availability time $3.585 \mathrm{jam}$. Dan memiliki rata - rata persentase loss time sebesar 7,09\%. Dan dari total loss time 256,11 jam, mesin IR welding merupakan penyumbang loss time tertinggi yaitu 228,32 jam, untuk persentase loss time mesin IR welding sebesar $6,37 \%$. sehingga loss time yang ada pada mesin yang lainnya yaitu 7,09\% - 6,37\% =0,72\%. Karena target loss time perusahaan 5\%, maka dilakukan perbaikan pada mesin $I R$ welding karena menimbulkan loss time melebihi target perusahaan yang telah ditentukan.

\section{Data Six Big Losses}

Data ini merupakan data breakdown time, set up time, produksi produk ideal, ideal cycle time, total produksi, total defect dan total defect awal produksi untuk mesin infrared welding lini LED winker lamp selama periode 2019. Data tersebut yang akan digunakan untuk menghitung six big losses. Breakdown time adalah loss time akibat terjadinya kerusakan pada mesin. Sedangkan set up time adalah loss time yang diakibatkan pergantian dan penyetelan peralatan atau jig.

Tabel 3.5 Data untuk Menghitung Six Big Losses 


\begin{tabular}{|l|c|c|c|c|c|c|}
\hline $\begin{array}{c}\text { Bulan } \\
(2019)\end{array}$ & $\begin{array}{c}\text { Breakdown } \\
\text { time (Jam) }\end{array}$ & $\begin{array}{c}\text { Set up } \\
\text { time } \\
\text { (Jam) }\end{array}$ & $\begin{array}{c}\text { Produksi } \\
\text { produk } \\
\text { ideal } \\
\text { (Pcs/jam) }\end{array}$ & $\begin{array}{c}\text { Ideal } \\
\text { Cycle } \\
\text { time } \\
\text { (Jam) }\end{array}$ & $\begin{array}{c}\text { Total } \\
\text { defect } \\
\text { (Pcs) }\end{array}$ & $\begin{array}{c}\text { Total } \\
\text { defect } \\
\text { awal } \\
\text { produksi } \\
\text { (Pcs) }\end{array}$ \\
\hline Januari & 6,25 & 11,55 & 180 & 0,0051 & 61 & 26 \\
\hline Februari & 9,50 & 5,70 & 180 & 0,0051 & 36 & 16 \\
\hline Maret & 9,50 & 12,18 & 180 & 0,0051 & 34 & 13 \\
\hline April & 5,33 & 14,43 & 180 & 0,0051 & 39 & 18 \\
\hline Mei & 7,83 & 12,92 & 180 & 0,0051 & 24 & 9 \\
\hline Juni & 6,50 & 9,27 & 180 & 0,0051 & 28 & 11 \\
\hline Juli & 7,92 & 7,48 & 180 & 0,0051 & 32 & 13 \\
\hline Agustus & 4,42 & 11,28 & 180 & 0,0051 & 45 & 21 \\
\hline September & 3,92 & 14,53 & 180 & 0,0051 & 40 & 17 \\
\hline Oktober & 6,08 & 19,73 & 180 & 0,0051 & 44 & 19 \\
\hline November & 8,58 & 15,73 & 180 & 0,0051 & 37 & 16 \\
\hline Desember & 8,50 & 9,17 & 180 & 0,0051 & 28 & 10 \\
\hline
\end{tabular}

Sumber : PT Mitsuba Indonesia (telah diolah)

\subsection{Pengolahan Data}

Ini merupakan tahap Plan (Perencanaan) dalam filosofi kaizen. Pada tahapan plan ini akan membahas tentang potensi perbaikan yang akan dilakukan. Berdasarkan pengumpulan data yang sudah dibahas diatas. Bahwa mesin Infrared Welding mengalami loss time yang tinggi sehingga berpengaruh terhadap output produksi yang ada pada lini LED winker lamp.

\section{Perhitungan Produktivitas Sebelum Perbaikan}

Berdasarkan tabel 3.1 dan tabel 3.2 diatas dapat dilakukan perhitungan produktivitas pada lini LED winker lamp, dimana pada lini LED winker lamp terdapat 7 orang operator. Maka perhitungannya untuk bulan Januari 2019 adalah sebagai berikut :

Produktivitas $=\frac{54.060 \text { pcs }}{22 \text { hari } \times 7 \text { orang }}=351,04$ pcs $/$ hari $/$ orang

\section{Perhitungan Six Big Losses}

Perhitungan six big losses ini digunakan untuk mengetahui faktor - faktor kerugian apa saja dari faktor six big losses yang menyebabkan rendahnya produktivitas pada mesin infrared welding. Maka dari hasil perhitungan ini dapat ditentukan pula faktor yang menjadi prioritas utama yang akan diperbaiki. Berikut ini merupakan perhitungan dari keenam kerugian tersebut.

\section{Downtime Losses}

Downtime Losses sendiri terdiri dari dua kerugian yaitu breakdown losses dan setup and adjustment losses. Berikut ini perhitungan dari kedua kerugian tersebut.

a) Breakdown or Equipment Failure Losses

Perhitungan Breakdown losses memerlukan data breakdown time dan loading time mesin. Data diambil dari tabel 3.2 dan 3.5, didapatkan nilai persentase breakdown losses untuk bulan Januari 2019 yaitu sebagai berikut:

Breakdown Losses $=\frac{6.25}{319} \times 100 \%=1,96 \%$

b) Set Up and Adjusment Losses

Perhitungan set up and adjustment losses memerlukan data set up mesin dan loading time mesin. Data diambil dari tabel 3.2 dan 3.5, dari data tersebut dapat dihitung sehingga didapatkan nilai persentase set up and adjustment losses untuk bulan Januari 2019 yaitu sebagai berikut: 
Set up and adjustment losses $=\frac{11.55}{319} \times 100 \%=3,62 \%$

2. Speed Losses

Speed losses terdiri dari dua kerugian yaitu idling and minor stoppages losses dan reduce speed losses. Berikut ini perhitungan dari kedua macam kerugian tersebut.

a) Idling and Minor Stoppages Losses

Perhitungan idling and minor stoppages losses memerlukan data loading time, operation time, nonproductive time, actual production time, jumlah produksi dan jumlah produksi ideal per jam. Data diambil dari tabel 3.2 dan 3.5, dari data tersebut terlebih dahulu dapat dihitung diperoleh :

Actual production time $=\frac{54060}{180}=300,33 \mathrm{jam}$

Setelah memperoleh nilai actual production time, maka dilakukan perhitungan sebagai berikut :

Nonproductive time $=293,70-300,33$

Karena nilai operation time lebih kecil daripada actual production time maka nilai nonproductive time sama dengan 0 (nol).

Dari perhitungan diatas maka dapat dilakukan perhitungan untuk mencari idling and minor stoppages losses dan didapatkan nilai persentase idling and minor stoppages losses untuk bulan Januari 2019 yaitu sebagai berikut:

Idling and minor stoppages losses $=\frac{O}{319} \times 100 \%=0 \%$

b) Reduce Speed Losses

Perhitungan reduce speed losses memerlukan data ideal cycle time, operation time, loading time dan total jumlah produksi. Data diambil dari tabel 3.2 dan 3.5, dari data tersebut dapat dihitung dan didapatkan nilai persentase reduce speed losses untuk bulan Januari 2019 yaitu sebagai berikut :

Reduce speed losses $=\frac{293,70-(0,0051 \times 54060)}{319} \times 100 \%=0,06 \%$

3. Defect or Quality Losses

Defect or Quality Losses terdiri dari dua kerugian yaitu quality defect (rework and defect losses) dan yield losses. Berikut ini perhitungan dari kedua macam kerugian tersebut.

a) Rework and Defect Losses

Perhitungan rework and defect losses memerlukan data total defect produk, ideal cycle time dan loading time. Data diambil dari tabel 3.2 dan 3.5, dari data tersebut dapat dihitung sehingga didapatkan nilai persentase rework and defect losses untuk bulan Januari 2019 yaitu sebagai berikut:

Defect losses $=\frac{61 \times 0.0051}{319} \times 100 \%=0,10 \%$

b) Yield Losses

Perhitungan yield losses memerlukan data produk defect setting awal, ideal cycle time dan loading time. Data diambil dari tabel 3.2 dan 3.5, dari data tersebut dapat dihitung sehingga didapatkan nilai persentase yield losses untuk bulan Januari 2019 yaitu sebagai berikut:

Yield losses $=\frac{26 \times 0.0051}{319} \times 100 \%=0,04 \%$

\subsection{Analisa dan Pembahasan}

\section{Analisa Six Big Losses}

Dalam six big losses ada beberapa kategori aktivitas yang menyebabkan losses pada mesin infrared welding diantaranya :

1) Idling and minor stoppages losses, yaitu: Part drop error.

2) Set up and adjustment losses, yaitu : Pergantian tipe jig produksi.

3) Breakdown losses, yaitu : Infrared lamp mati (error).

4) Reduce speed losses, yaitu : Timbul noise (bising). 
5) Rework and defect losses, yaitu : NG welding.

6) Yield losses, yaitu : Hasil welding terdapat bubble.

Data dapat dilihat pada Tabel 3.6 yang memperlihatkan rata - rata losses, total loss time, persentase loss time dan persentase kumulatif untuk masing - masing losses.

Tabel 3.6 Hasil Perhitungan Six Big Losses Tahun 2019

\begin{tabular}{|c|c|c|c|c|}
\hline Jenis losses & $\begin{array}{l}\text { Rata - rata } \\
\text { losses }(\%)\end{array}$ & $\begin{array}{c}\text { Total loss time } \\
\text { (Jam) }\end{array}$ & $\begin{array}{c}\text { Persentase } \\
\text { losstime } \\
(\%)\end{array}$ & $\begin{array}{c}\text { Persentase } \\
\text { kumulatif }(\%)\end{array}$ \\
\hline $\begin{array}{l}\text { Idling minor and } \\
\text { stoppages losses }\end{array}$ & 7,08 & 116,46 & 51,01 & 51,01 \\
\hline $\begin{array}{l}\text { Setup and } \\
\text { adjusment losses }\end{array}$ & 4,12 & 67,77 & 29,68 & 80,69 \\
\hline Breakdown losses & 2,46 & 40,47 & 17,72 & 98,41 \\
\hline $\begin{array}{l}\text { Reduce speed } \\
\text { losses }\end{array}$ & 0,12 & 1,97 & 0,86 & 99,28 \\
\hline $\begin{array}{l}\text { Rework and } \\
\text { defect losses }\end{array}$ & 0,07 & 1,15 & 0,50 & 99,78 \\
\hline Yield losses & 0,03 & 0,49 & 0,22 & 100,00 \\
\hline Total & 13,88 & 228,32 & 100,00 & \\
\hline
\end{tabular}

Dari Tabel 3.6 di atas dapat pula dilihat menggunakan diagram pareto, seperti pada gambar 3.1 berikut ini.

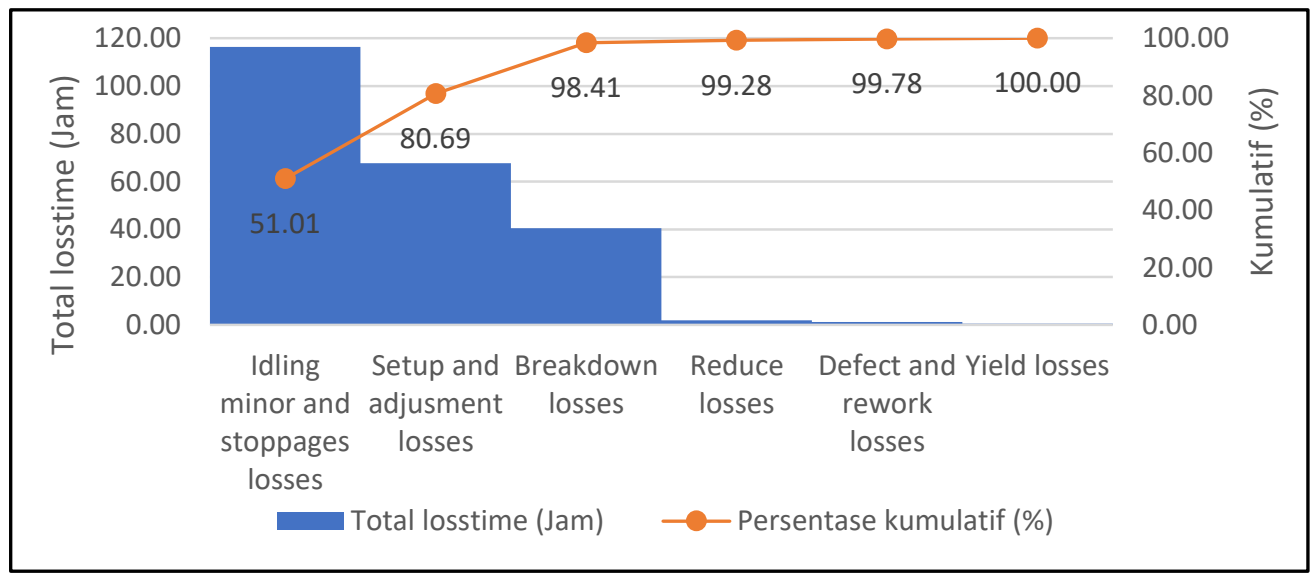

Gambar 3.1 Diagram Pareto Six Big Losses

Berdasarkan data hasil perhitungan Six Big Losses yang ditampilkan pada Tabel 3.6 diatas, diketahui bahwa nilai losses tertinggi adalah Idling minor and stoppages losses dengan total loss time 116,46 jam atau 51,01\% dari total loss time mesin infrared welding selama periode bulan Januari - Desember 2019. Nilai tertinggi kedua adalah Setup and adjusment losses yaitu sebesar 67,77 jam atau 29,68 \% dari total loss time. Persentase kumulatif dari kedua losses tersebut sebesar $80,69 \%$, dan target loss time perusahaan yaitu $5 \%$, dengan perhitungan $80,69 \%$ dari $5 \%$ diperoleh $4,03 \%$. Sedangkan loss time yang ada di lini LED winker lamp yaitu 7,09\%, sehingga apabila 7,09\% - 4,03\% $=3,06 \%$. Maka dengan melakukan perbaikan pada kedua losses tersebut dapat menurunkan loss time dibawah target yang sudah ditentukan perusahaan. 


\section{Analisa Sebab Akibat}

Tahap selanjutnya mencari akar penyebab dari munculnya keenam losses tersebut.

1. Idling minor and stoppages losses

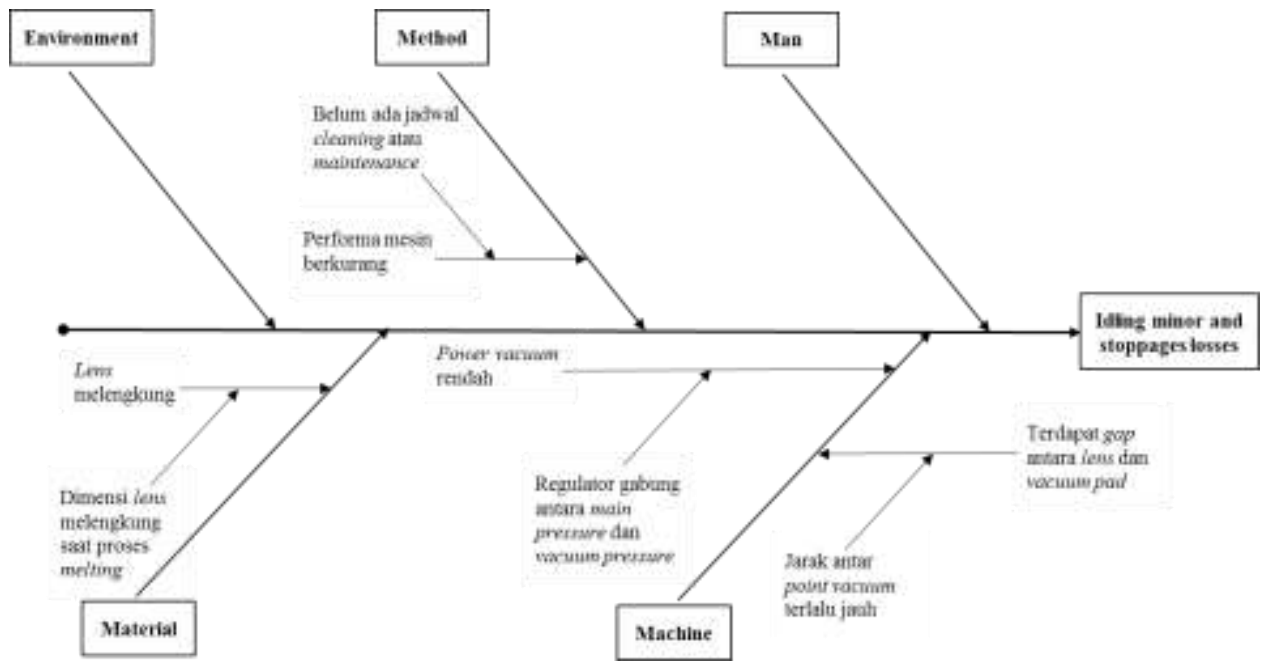

Gambar 3.2 Diagram Sebab Akibat Idling Minor and Stoppages Losses

2. Set up and adjusment losses

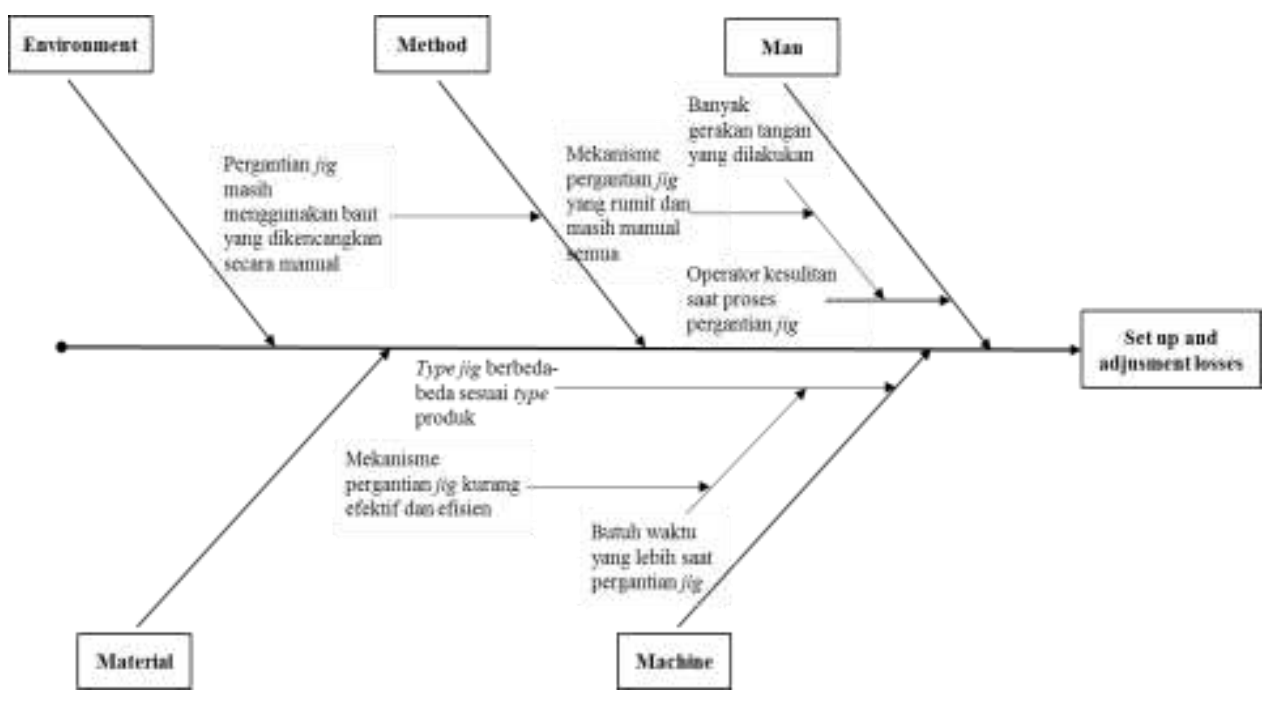

Gambar 3.3 Diagram Sebab Akibat Set Up and Adjusment Losses

Setelah dilakukan analisa sebab akibat terhadap kedua faktor yang menyebabkan losses paling besar nilai komulatifnya diatas maka dapat direncanakan mengenai perbaikannya.

Tahapan berikutnya adalah Do (Pelaksanaan) perbaikan yang sudah direncanakan. Perbaikan yang akan dilakukan yaitu pada faktor idling minor and stoppages losses dan set up and adjusment losses. Dimana faktor idling minor and stoppages losses disebabkan oleh part drop error dan set up and adjusment losses yang disebabkan karena pergantian tipe jig produksi 
Tabel 3.7 Perbaikan Tehadap Faktor Losses Part Drop Error

\begin{tabular}{|l|l|l|}
\hline Kategori & \multicolumn{1}{|c|}{ Rootcause } & \multicolumn{1}{c|}{ Perbaikan } \\
\hline Machine & $\begin{array}{l}\text { Main pressure dan vacuum } \\
\text { pressure terdapat pada 1 } \\
\text { regulator. }\end{array}$ & $\begin{array}{l}\text { Menambah 1 set regulator } \\
\text { khusus untuk vacuum pressure. }\end{array}$ \\
\hline Machine & $\begin{array}{l}\text { Jarak antar point vacuum } \\
\text { (vacuum pad) terlalu jauh. }\end{array}$ & $\begin{array}{l}\text { Memodifikasi dengan } \\
\text { mengubah jarak antar point } \\
\text { vacuum pada suction plate dan } \\
\text { lens set jig menjadi lebih dekat. }\end{array}$ \\
\hline Method & $\begin{array}{l}\text { Tidak ada jadwal cleaning } \\
\text { atau maintenance }\end{array}$ & $\begin{array}{l}\text { Membuat checklist cleaning } \\
\text { pada mesin secara berkala. }\end{array}$ \\
\hline Material & $\begin{array}{l}\text { Lens melengkung pada } \\
\text { bagian tengah saat proses } \\
\text { melting karena tidak ada } \\
\text { yang menahan. }\end{array}$ & $\begin{array}{l}\text { Memodifikasi dengan } \\
\text { mengubah jarak antar point } \\
\text { vacuum pada suction plate dan } \\
\text { lens set jig menjadi lebih dekat } \\
\text { untuk menahan bagian tengah } \\
\text { lens. }\end{array}$ \\
\hline
\end{tabular}

Tabel 3.8 Perbaikan Tehadap Faktor Losses Pergantian Tipe Jig Produksi

\begin{tabular}{|l|l|l|}
\hline Kategori & \multicolumn{1}{|c|}{ Rootcause } & \multicolumn{1}{|c|}{ Perbaikan } \\
\hline Man & $\begin{array}{l}\text { Belum adanya mekanisme } \\
\text { dalam pergantian semua jig } \\
\text { yang semi-otomatis yang } \\
\text { memudahkan operator. }\end{array}$ & $\begin{array}{l}\text { Membuat mekanisme } \\
\text { pergantian lower and upper } \\
\text { heater jig secara semi- } \\
\text { otomatis yang memudahkan } \\
\text { operator. }\end{array}$ \\
\hline Machine & $\begin{array}{l}\text { Sistem penguncian pada upper } \\
\text { heater jig dan lower heater jig } \\
\text { masih manual menggunakan 8 } \\
\text { baut (@2x4 pcs) per station. }\end{array}$ & $\begin{array}{l}\text { Mengganti sistem penguncian } \\
\text { pada lower and upper heater } \\
\text { jig dengan menggunakan } \\
\text { clamp lever sebanyak 2 pcs } \\
\text { per station ditambah otomatis } \\
\text { menggunakan cylinder. }\end{array}$ \\
\hline Method & $\begin{array}{l}\text { Metode pemasangan dan } \\
\text { pelepasan lower and upper } \\
\text { heater jig menggunakan pin } \\
\text { positioning dengan arah up } \\
\text { down. }\end{array}$ & $\begin{array}{l}\text { Mengganti metode } \\
\text { pemasangan dan pelepasan } \\
\text { lower and upper heater jig } \\
\text { menggunakan sistem slider } \\
\text { dengan arah front back. }\end{array}$ \\
\hline
\end{tabular}

\section{Pembahasan}

Tahap berikutnya Check (Pemeriksaan) perbaikan yang sudah dilakukan.

a. Perhitungan Persentase Loss Time Mesin Infrared Welding setelah Perbaikan

Pelaksanaan perbaikan dilakukan pada bulan Januari dan Februari. Tetapi karena terkendala suatu dan lain hal, maka pengambilan hasil dan evaluasi mulai dilakukan pada bulan Juli dan bulan Agustus tahun 2020. Berdasarkan data pada lini LED winker lamp bahwa pada bulan Juli diketahui availability time 240 jam, dengan total loss time 11,67 jam. Jadi persentase loss time dihitung dengan persamaan :

Persentase Loss Time $=\frac{11,67}{240} \times 100 \%=4,86 \%$ 
Dengan perhitungan yang sama pada bulan Agustus, maka dapat dilihat pada tabel berikut ini :

Tabel 3.9 Loss Time Sesudah Kaizen

\begin{tabular}{|l|c|c|c|}
\hline Bulan (2020) & $\begin{array}{c}\text { Availability } \\
\text { time (Jam) }\end{array}$ & $\begin{array}{c}\text { Loss time } \\
\text { (Jam) }\end{array}$ & $\begin{array}{c}\text { Loss time } \\
(\%)\end{array}$ \\
\hline Juli & 240 & 11,67 & 4,86 \\
\hline Agustus & 225 & 10,58 & 4,70 \\
\hline Rata - rata & 232,5 & 11,13 & 4,78 \\
\hline
\end{tabular}

Sumber : PT Mitsuba Indonesia

Berdasarkan tabel diatas, bahwa pada bulan Juli dan bulan Agustus availabilty time lebih kecil daripada availability time pada tahun 2019, hal ini disebabkan karena jumlah hari kerja pada lini yang dilakukan perbaikan lebih sedikit yaitu pada bulan juli 16 hari dan bulan agustus 15 hari. Dan sisanya produksi di lini yang lainnya. Biasanya dalam sebulan ada 22 hari kerja.

Dapat dilihat bahwa loss time setelah dilakukan perbaikan turun menjadi 4,86\% pada bulan Juli dan turun 4,70\% pada bulan Agustus. Penurunan loss time ini sudah dibawah standar maksimal perusahaan yang diperbolehkan yaitu 5\%. Artinya dengan perbaikan yang sudah dilakukan maka target dari perusahaan terpenuhi. Untuk melihat lebih jelas penurunan loss time pada lini LED winker lamp dapat dilihat pada gambar berikut ini.

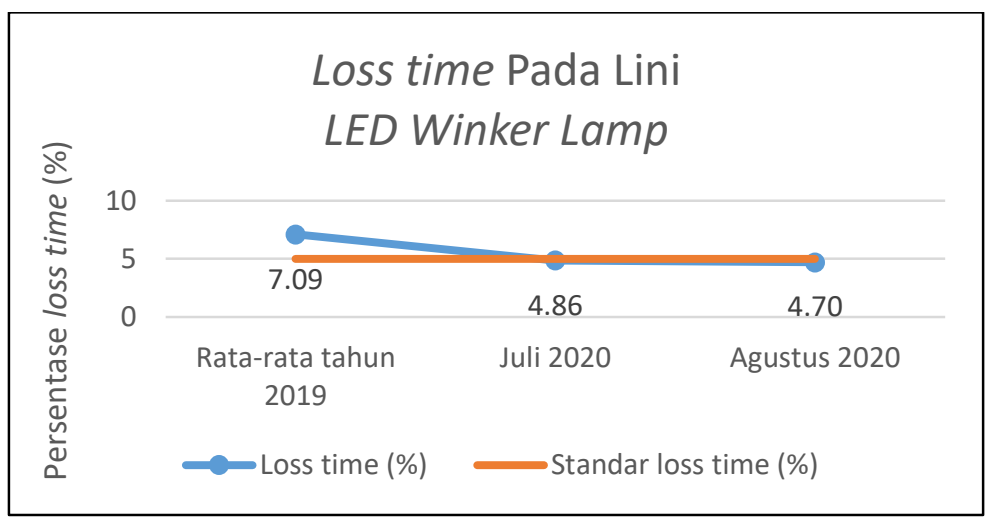

Gambar 3.4 Perbandingan Loss Time Sebelum dan Sesudah Kaizen

Setelah adanya penurunan loss time maka hasil pencapaian produksi mengalami peningkatan, dapat dilihat pada gambar berikut ini. 


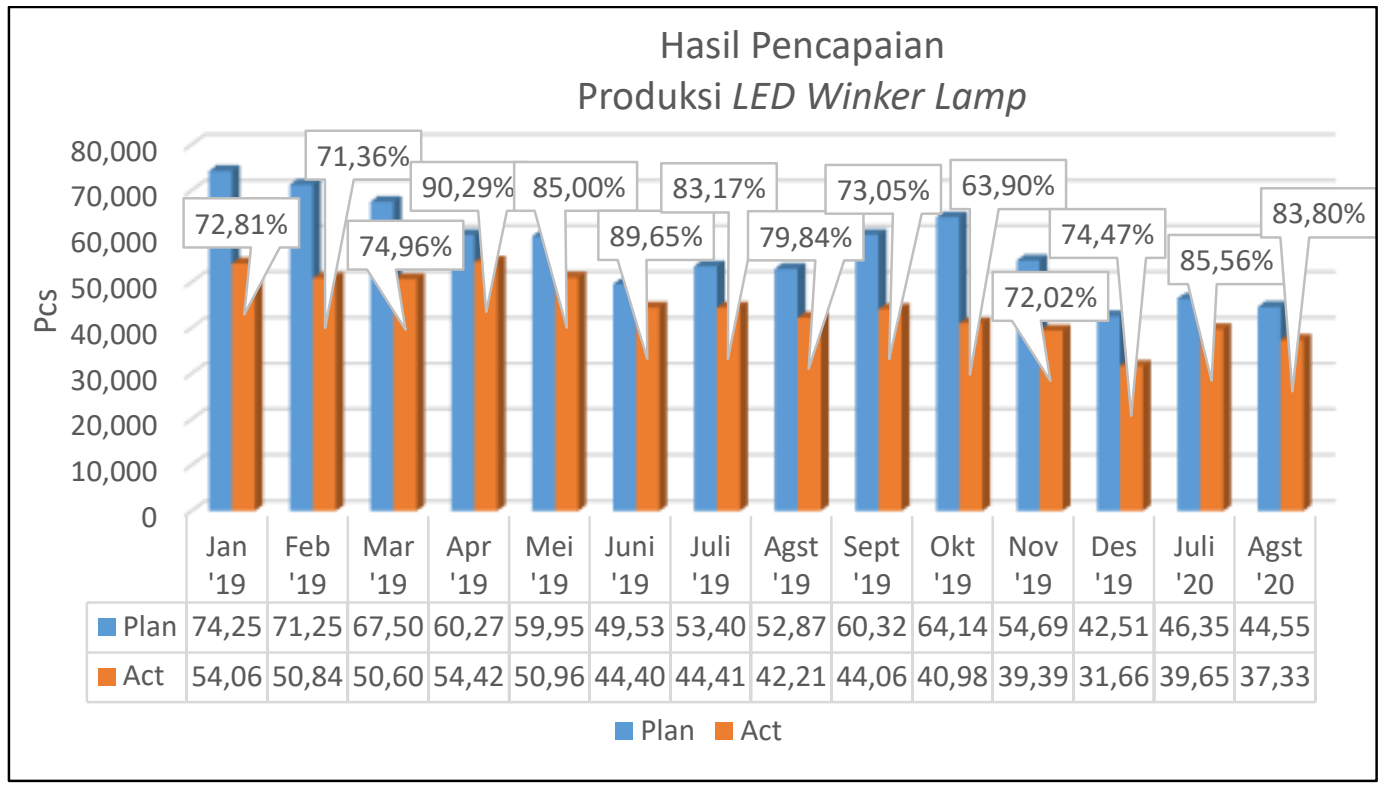

Gambar 3.5 Pencapaian Produksi Sebelum dan Sesudah Kaizen Sumber : PT Mitsuba Indonesia

Setelah dilakukan kaizen hasil pencapaian produksi pada lini LED winker lamp mengalami peningkatan dari plan produksi yaitu pada bulan Juli $85,56 \%$ dan pada bulan Agustus 83,80\%.

\section{b. Perhitungan Produktivitas setelah Perbaikan}

Berdasarkan adanya peningkatan hasil pencapaian produksi yang ditampilkan pada Gambar 3.5 dan jumlah hari kerja pada Tabel 3.10 dibawah, maka dilakukan perhitungan produktivitas bulan Juli 2020 dapat dihitung :

Produktivitas $=\frac{39.659 \mathrm{pcs}}{16 \text { hari } \times 7 \text { orang }}=354,10 \mathrm{pcs} /$ hari/orang

Dengan persamaan yang sama juga dilakukan perhitungan produktivitas pada bulan Agustus. Sehingga dapat ditampilkan pada tabel berikut ini.

Tabel 3.10 Produktivitas Setelah Perbaikan

\begin{tabular}{|l|c|c|c|}
\hline $\begin{array}{c}\text { Bulan } \\
(2020)\end{array}$ & $\begin{array}{c}\text { Output Produksi } \\
(\mathrm{Pcs})\end{array}$ & $\begin{array}{c}\text { Waktu Kerja } \\
\text { (Hari) }\end{array}$ & $\begin{array}{c}\text { Produktivitas } \\
(\text { Pcs/Hari/Orang) }\end{array}$ \\
\hline Juli & 39,659 & 16 & 354,10 \\
\hline Agustus & 37,332 & 15 & 355,54 \\
\hline Rata - rata & 38,496 & 15,50 & 354,82 \\
\hline
\end{tabular}

Sumber : PT Mitsuba Indonesia (telah diolah)

Dari tabel diatas, dapat dilihat bahwa produktivitas setelah dilakukan perbaikan naik 7,5\% dari rata - rata produktivitas tahun 2019 menjadi 354,10 pcs/hari/orang pada bulan Juli 2020 dan naik 7,9\% dari rata - rata produktivitas tahun 2019 menjadi 355,54 pcs/hari/orang pada bulan Agustus 2020. Kenaikan produktivitas ini sudah memenuhi target perusahaan yaitu produktivitas naik $5 \%$ pada setiap tahunnya. Artinya dengan perbaikan yang sudah dilakukan maka target dari perusahaan terpenuhi. Untuk melihat lebih jelas peningkatan produktivitas pada lini LED winker lamp dapat dilihat pada gambar berikut ini. 


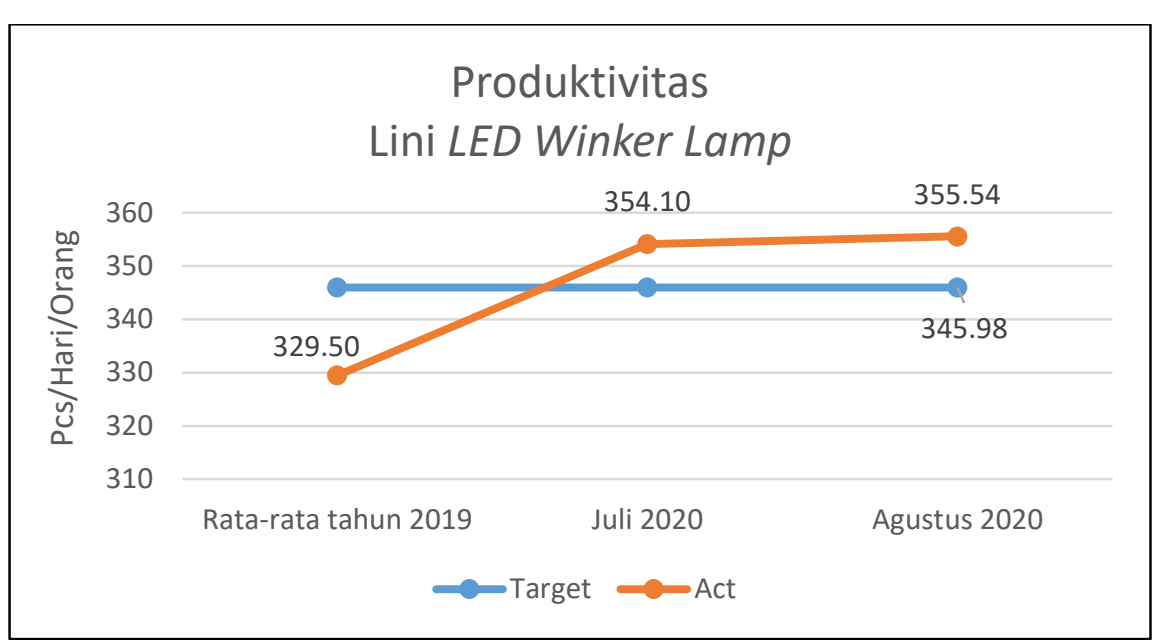

Gambar 3.6 Perbandingan Produktivitas Sebelum dan Sesudah Perbaikan

Pada gambar diatas, dapat dilihat bahwa nilai 345,98 pcs/hari/orang merupakan hasil dari target perusahaan yaitu naik 5\% dari rata - rata tahun 2019. Jadi 329,50 x 5\% $=16,48$. Target kenaikan produktivitas di tahun 2020 sebesar 16,48 pcs/hari/orang atau menjadi $16,48+329,50=345,98 \mathrm{pcs} /$ hari/orang.

Setelah dilakukan pengecekan maka langkah terakhir adalah melakukan Action (Tindakan) lanjutan. Tindakan yang diambil yaitu dengan cara dibuatkan standarisasi pada perbaikan yang sudah dilakukan. Pada perbaikan pertama yaitu perbaikan akibat part drop error losses dibuatkan standarisasi yaitu penambahan 1 set regulator untuk vacuum pressure. Selanjutnya dibuatkan check sheet control item pada mesin infrared welding yaitu pengontrolan secara berkala terhadap kondisi mesin agar performa mesin optimal.

\section{KESIMPULAN DAN SARAN}

\subsection{Kesimpulan}

Berdasarkan pembahasan diatas maka dapat diambil kesimpulan sebagai berikut :

1. Penyebab yang menimbulkan loss time pada lini LED winker lamp yaitu :

a. Part drop error

b. Pergantian tipe jig produksi

c. Infrared lamp mati (error)

d. Timbul noise (bising)

e. $N G$ welding

f. Hasil welding terdapat bubble

2. Perbaikan yang dilakukan untuk menurunkan loss time yaitu :

a. Part drop error, perbaikan yang dilakukan antara lain :

i. Menambah 1 set regulator khusus untuk vacuum pressure.

ii. Memodifikasi dengan mengubah jarak antar point vacuum pada suction plate dan lens set jig menjadi lebih dekat.

iii. Membuat checklist cleaning pada mesin secara berkala.

iv. Memodifikasi dengan mengubah jarak antar point vacuum pada suction plate dan lens set jig menjadi lebih dekat untuk menahan bagian tengah lens.

b. Pergantian tipe jig produksi, perbaikan yang dilakukan antara lain :

i. Membuat mekanisme pergantian lower and upper heater jig secara semiotomatis yang memudahkan operator.Mengganti sistem penguncian pada lower and upper heater jig dengan menggunakan clamp lever sebanyak 2 pcs per station ditambah otomatis menggunakan cylinder. 
ii. Mengganti metode pemasangan dan pelepasan lower and upper heater jig menggunakan sistem slider dengan arah front back.

iii. Mengganti metode pemasangan dan pelepasan lower and upper heater jig menggunakan sistem slider dengan arah front back.

3. Rata - rata loss time pada lini LED winker lamp tahun 2019 yaitu 7,09\%. Setelah dilakukan perbaikan loss time turun menjadi $4,86 \%$ pada bulan Juli 2020 dan turun 4,70\% pada bulan Agustus 2020. Penurunan loss time ini sudah dibawah standar maksimal perusahaan yang diperbolehkan yaitu $5 \%$.

4. Rata - rata produktivitas pada lini LED winker lamp tahun 2019 yaitu 329,50 pcs/hari/orang. Setelah dilakukan perbaikan naik $7,5 \%$ dari rata - rata produktivitas tahun 2019 menjadi 354,10 pcs/hari/orang pada bulan Juli dan naik 7,9\% dari rata - rata produktivitas tahun 2019 menjadi 355,54 pcs/hari/orang pada bulan Agustus. Kenaikan produktivitas ini sudah memenuhi target perusahaan yaitu produktivitas naik $5 \%$ pada setiap tahunnya.

\subsection{Saran}

1. Perbaikan yang dilakukan pada penelitian ini hanya pada 2 penyebab loss time. Agar hasil lebih maksimal perlu dilakukan perbaikan secara menyeluruh terhadap 6 penyebab loss time.

2. Karena keterbatasan penulis dalam proses penelitian, sehingga penerapan kaizen yang dilakukan tidak membahas masalah biaya, akan lebih sempurna lagi apabila membahas biaya yang dikeluarkan.

3. Evaluasi hasil setelah dilakukan penerapan kaizen terbatas hanya 2 bulan. Oleh karena itu, perlu dilakukan evaluasi selama 1 tahun untuk mengetahui seberapa optimal perbaikan yang sudah dilakukan.

\section{DAFTAR PUSTAKA}

Arif, M. S., Putri, C. F. and Tjahjono, N. (2018) 'Peningkatan Grade Kain Sarung dengan Mengurangi Cacat Menggunakan Metode Kaizen dan Siklus PDCA pada PT . X', Jurnal Widya Teknika, 26(2), pp. 222-231.

Darmawan, H., Hasibuan, S. and Purba, H. H. (2018) 'Application of Kaizen Concept with 8 Steps PDCA to Reduce in Line Defect at Pasting Process: A Case Study in Automotive Battery', International Journal of Advances in Scientific Research and Engineering, 4(8), pp. 97-107.

Depvi, T. S. (2017). Analisis Strategi Pemasaran dan Pengembangan Usaha Pada Sentra Industri Mebel PT. Pandu Wira Desa Sukorejo Kecamatan Bojonegoro Kabupaten Bojonegoro. Skripsi. Fakultas Ekonomi, Universitas Bojonegoro.

Fatkhurrohman, A. and Subawa (2016) 'Penerapan Kaizen Dalam Meningkatkan Efisiensi Dan Kualitas Produk Pada Bagian Banbury PT Bridgestone Tire Indonesia', Jurnal Administrasi Kantor, 4(1), pp. 14-31.

Gani, A. J. and Bendatu, L. Y. (2015) 'Perbaikan Proses Dandori di PT. Astra Otoparts Tbk . Divisi Adiwira Plastik', Jurnal Titra, 3(2), pp. 1-8.

Ihsan, M. (2019) 'Fanuc Cnc Machine Damage Analysis Using The Pdca Cycle And Kaizen Implementation Effort In Increasing Skill Up Operator Performance In Pt Ypmi', Independent Journal Of Management \& Production (IJM\&P), 10(February), pp. 259-280.

Imai, M. (2001). Kaizen (Ky'zen): Kunci Sukses Jepang Dalam Persaingan, Cetakan kelima, diterjemahkan oleh Dra. Mariani Gandamihardja. Penerbit PPM.

Kapuria, T. K., Rahman, M. and Haldar, S. (2017) 'Root Cause Analysis and Productivity Improvement of An Apparel Industry in Bangladesh Through Kaizen Implementation', Journal Aprie, 4(4), pp. 227-239. 
Kartika, H. (2020) 'Lean Kaizen untuk Meningkatkan Produktivitas Line Painting pada Bagian Produksi', Jurnal Sistem Teknik Industri, 22(1), pp. 22-32.

Kurnia, I. and Suryanto (2018) 'Efesiensi Waktu Kerja Proses Packaging dengan Metode PDCA (Plan Do Check Action) di PT Lemindo Abadi Jaya', Jurnal Teknik Industri. Universitas Krisnadwipayana, pp. 10-20.

Nagaich, R., Tiwari, L. and Sahu, S. (2020) 'Productivity Improvement By Kaizen : A Case Study In A Tyre Company', Industrial Engineering Journal, 13(2), pp. 1-12.

Pinasthika., A. (2018). Analisis Perhitungan Overall Equipment Effectiveness (OEE) Guna Mengurangi Six Big Losses Dan Upaya Perbaikan Dengan Pendekatan Kaizen 5S (Studi Kasus: PT.PINDAD (PERSERO). Skripsi. Fakultas Teknologi Industri, Universitas Islam Indonesia.

Rizqilah, C., Silviana and Hardianto, A. (2019) 'Penerapan Konsep Continuous Improvement Untuk Mengoptimalkan Penggunaan Energi pada Mesin Pengering ( Dryer Device) di RTC Line PT . HM', Jurnal Conference on Innovation and Application of Science and Technology. Universitas Widyagama Malang, (Ciastech), pp. 225-230.

Roro, R., Herdiana, L and Husniah, H. (2020) 'Analisis Perhitungan Overall Equipment Effectiveness Guna Mengurangi Six Big Losses dan Upaya Perbaikan Dengan Pendekatan Kaizen 5S', Jurnal TIARSIE, 17(2), pp. 53-56.

Sari, L. P., Islamuddin and Finthariasari., M. (2020) 'Pengaruh Etos Kerja Dan Lingkungan Kerja Terhadap Produktivitas Kerja Karyawan Pada Industri Kerupuk As-Syifa Kota Bengkulu', Jurnal Entrepreneur dan manajemen Sains (JEMS), 1(2), pp. 216221.

Setiawan, D. (2019) 'Peningkatan Kapasitas Produksi Mesin Press pada Panel Front Door Outer RH Sebagai Upaya Meningkatkan Produktivitas Press Shop pada Industri Otomotif', Jurnal Integrasi Sistem Industri, 6(1), pp. 37-43.

Sharma, P., Sharma, N. K. and Singh, M. P. (2015) 'Process Improvement By Implementation Of Kaizen As A Quality Tool Within Defined Constraints : A Case Study In Manufacturing', International Journal of Science and Technology, 1(1), pp. 182-194.

Sinungan, M. (2014). Produktivitas Apa Dan Bagaimana. Jakarta: PT Bumi Aksara.

Siswandi and Karomah, N. G. (2019) 'Implementasi Sistem Keizen Departemen Produksi PT Yamaha Music Manufacturing Asia Bekasi - Jawa Barat', Jurnal Akuntansi dan Bisnis, 5(01), pp. 1-17.

Suwardiyanto, P., Siregar, D. and Umar, D. (2020) 'Analisis Perhitungan OEE dan Menentukan Six Big Losses pada Mesin Spot Welding Tipe X', Journal of Industrial and Engineering Sistem (JIES), 1(1), pp. 11-20. 
